\title{
Jeśli nie interpretacja, to co?
}

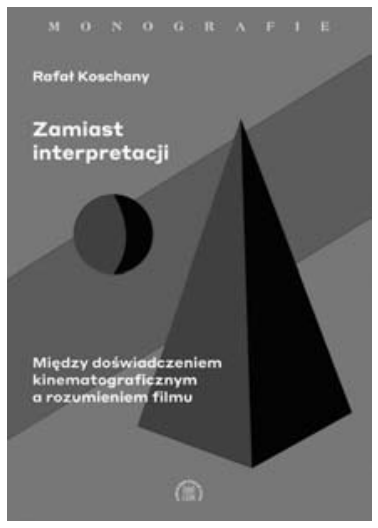

\author{
TERESA RUTKOWSKA
}

Jesteśmy w niej zanurzeni z głową i po czubki palców. Od lat 60. stanowi podstawową strategię badawczą filmoznawstwa, koło zamachowe zarówno teorii, jak i historii filmu, wyrosłych przecież na bazie myśli o sztuce, literaturoznawstwa i oczywiście filozofii. Umberto Eco, odwołując się do metafory świata jako tekstu i tekstu jako świata, proponuje jej definicję najogólniejszą z możliwych. Interpretacja - bo o niej tu mowa - jest według niego reakcją na tekst świata i świat tekstu przez produkowanie innych tekstów ${ }^{1}$. A to w rezultacie staje się sensem istnienia uniwersytetów i uprawiania humanistyki jako takiej. Jednak każdy zwrot w humanistyce - semiotyczny, strukturalistyczny, fenomenologiczny, hermeneutyczny, psychoanalityczny, poststrukturalistyczny czy kognitywistyczny - otwiera nową przestrzeń dla praktyk interpretacyjnych, kwestionuje wcześniejsze, anektuje je lub wzbogaca.

Książka Rafała Koschanego nosi intrygujący tytuł Zamiast interpretacji, będący oczywistym i znaczącym nawiązaniem do słynnego eseju Susan Sontag Przeciw interpretacji z 1964 r. ${ }^{2}$, i została napisana pod prąd zasygnalizowanej na początku tendencji. Autor wyznaczył sobie zadanie trudne, by nie powiedzieć karkołomne, bowiem postanowił stawić czoło hegemonii interpretacji filmoznawczych, przedrzeć się przez gąszcz teorii z nimi związanych, by przyjmując perspektywę interdyscyplinarną, wydobyć tylko te stanowiska czy koncepcje, które w wyraźny sposób odcinaja się od ,, kultury znaczenia” (pojęcie Gumbrechta), polemizuja z nia, proponuja jakieś alternatywne rozwiązania (s. 40) ${ }^{3}$.

Wróćmy na chwilę do Susan Sontag. Jej bezkompromisowy protest wyrósł na gruncie konkretnej sytuacji kulturowej lat 60., jeszcze przed kulminacją ruchów kontestacyjnych, ale w pewnym aspekcie je zapowiadał, między innymi w końcowym, wywrotowym apelu: Potrzebujemy nie hermeneutyki, ale erotyki sztuki, wybrzmiewającym pełniej i niejako dosłowniej w kontekście innych zamieszczonych w tym samym tomie esejów. Choć wyzbyty impulsu politycznego, głos ten jest skierowany przede wszystkim przeciwko hermeneutyce wyrastającej z inspiracji psychoanalitycznej i marksistowskiej. W kulturze, której zasadniczym problemem jest nadmierny rozrost intelektu dokonujacy się kosztem świeżości i zdolności odczuwania, interpretacja stanowi zemstę intelektu na sztuce. Sontag wskazywała, że zwłaszcza sztuka współczesna z założenia i celowo wymyka się interpretacji (Eco miał na to gotową odpowiedź: Bądźmy realistami: nic nie jest petniejsze znaczenia niż tekst, który podkreśla, że nie ma znaczenia $\left.{ }^{4}\right)$. Proponowała, by docenić 
formę, powierzchnię sztuki bez rozgrzebywania jej wnętrzności, a przede wszystkim, by nauczyć się widzieć, słyszeć, odczuwać, co można uznać za pewną niekonsekwencję, ponieważ za powszechny błąd myślenia krytycznego uważała równocześnie oddzielenie treści od formy dzieła (i nadwartościowanie tej pierwszej). Radykalny esej Sontag wydaje się chwilami nieco anachroniczny, gdy na przykład faworyzuje film jako sztukę wolną jeszcze od owej presji interpretacyjnej, ponieważ jednak zarazem przywraca ważność bezpośredniemu doświadczeniu, zmysłowej ekscytacji, przyjemności, stanowi dla Koschanego doskonały punkt wyjścia, ale też lejtmotyw całej książki. Autor prowadzi swój wywód paradoksalnie po swoistym kole hermeneutycznym (bywa że - trzeba to powiedzieć - czasem nieco wyboistym) od teorii postulujących badanie dzieła filmowego ,poza interpretacją", przez te, które poszerzają samo to pojęcie lub zmieniają je czy sytuują w kontekstach wcześniej słabo uwzględnianych (jak zmienna historycznie recepcja, psychologia odbioru, organizacja i systemy produkcji wraz z uwarunkowaniami ekonomicznymi, politycznymi i kulturowymi) po to, by wrócić do metod interpretacyjnych, ale opartych na nowych zasadach. Za sprawą rewolucji technologicznej badacze zyskali bowiem narzędzia (VHS, DVD i wszelkie możliwości zapisu elektronicznego) pozwalające im pokonać nieadekwatność tworzywa, jakim jest język, wobec ulotnego przepływu obrazów; dostali też szansę, o której przed laty najbardziej wnikliwi widzowie filmów mogli tylko marzyć - mogą ową uporczywą płynność obrazu okiełznać w każdym wybranym momencie. To wszystko ostatecznie prowadzi autora do „miękkiego" postulatu, by „czynić swoje” i opisywać - analizować-wreszcie interpretować, a jednocześnie poddawać namysłowi owe praktyki, których się podejmuje (s. 53).

Centrum tych rozważań jest tu jednak ostatecznie film jako dzieło sztuki ruchomych obrazów, któremu przysługują takie atrybuty, jak niematerialność, audiowizualność, czasowość i ściśle z tym związana wspomniana ulotność, a przy tym zdolność oddziaływania na widza w aspekcie psychicznym, emocjonalnym i somatycznym. W poszukiwaniu wsparcia intelektualnego dla argumentu ,zamiast teorii interpretacji” autor odwołuje się na początek do Barthes'owskiego „trzeciego sensu", który uważa za kluczową dla całej teorii tego badacza - zwłaszcza w odniesieniu do fotografii i filmu, ale nie tylko - metafore epistemologiczna: to jakby stop-klatka w procesie interpretacji, jej zatrzymanie czy zerwanie, je dno c z eśnie rodzaj epifanii, objawienia (...) zakrytego dotąd sensu (s. 65), który nie daje się zwerbalizować, ale domaga się uznania dla rozumienia bez interpretacji.

W tym ujęciu ważności nabiera jedna z dróg, jaką podąża Nowa Historia Filmu mająca przywrócić należne miejsce procesom odbiorczym, doświadczeniu kina jako atrakcji. To - dowodzi Koschany - sprawia, że interpretacja utworu artystycznego w badaniach nad dziejami kina musi nieco ustąpić miejsca historii instytucji kinematograficznych z uwzględnieniem wielorakich czynników wpływających na ich funkcjonowanie. W związku z tematem pracy interesuje go jednak przede wszystkim historia i style odbioru filmu, a co za tym idzie, ,interpretacja interpretacji”, a także „historia interpretacji” zwłaszcza dzieł stawiających tym procedurom największy opór, jak legendarne już Zeszłego roku w Marienbadzie Alaina Resnais'ego czy Powiększenie Michelangela Antonioniego. Sięga do konkretnych propozycji, łącząc intuicje Susan Sontag z wspomnianego eseju i refleksje wybitnego krytyka Konrada Eberhardta, którzy waloryzują siłę kontemplacyjną niezwykłego 
dzieła Resnais'ego i jego formę. W tym przypadku nierozstrzygalna pozostaje kwestia, czy filmy takie nie dają się rozszyfrować, skazując wszelkie próby interpretacyjne na niepowodzenie, czy też przeciwnie - są raczej otwarte na wiele możliwych interpretacji (niezwykle obszerny przypis odnotowuje kilkadziesiąt propozycji, głównie polskich, ale nie tylko). Autor przywołuje też ,pozainterpretacyjne" strategie definiowania takich nurtów w kinie, jak na przykład slow cinema, które z założenia skupia się na powierzchni zjawisk i ich kontemplacji (bezinteresownej?), nie oferując zagadki do rozszyfrowania w postaci ukrytych znaczeń.

„Przeciw interpretacji” konstruowane są też zdaniem Koschanego filmy „kłopotliwe" (offending, by sięgnąć do terminologii W. J. T. Mitchella), które mają porazić odbiorcę wizją stanów granicznych, śmiertelnej choroby czy widokiem cudzego cierpienia (by znów przywołać Sontag) i prowokować próbę wykroczenia poza język (s. 115), w imię zgody na istnienie sfery „niewypowiedzianego”, co staje się jedynym możliwym odbiorczym gestem etycznym. Koschany podsuwa tu przykład takich filmów, jak Życie jako śmiertelna choroba przenoszona droga płciowa (reż. Krzysztof Zanussi, 2000), Miłość (Amour, reż. Michael Haneke, 2012) czy Dowcip (Wit, reż. Mike Nichols, 2001), a także kilku innych, które niejako wystawiają na próbę wytrzymałość widza, wprawiając go w stan oniemienia.

W kolejnym rozdziale pt. Poetyki i taktyki odbioru autor dokonuje opisu doświadczeń odbiorczych zasadzających się nie tyle na poszukiwaniu sensu dzieła, ile na jego przeżyciu kinematograficznym, na doświadczeniu jako niedowartościowanej dotą i niewystarczajaco opisanej formie uczestnictwa w kulturze i obcowania ze sztuka (s. 127). Przekonuje, że wbrew dość powszechnym przekonaniom o spadku znaczenia odbioru kinowego na rzecz tendencji do „prywatyzowania” kontaktu z dziełem filmowym za sprawą rewolucji elektronicznej, seans kinowy, instytucje festiwali i przeglądów filmowych w dalszym ciągu pozostają kluczowymi składnikami tego doświadczenia, wobec którego metafora jaskini Platona, stan swoistej hipnozy czy snu na jawie lub przeżycia parareligijnego nie straciły na istotności, co prowokuje do badań wielorakich reakcji widza, a także do diagnozowania możliwości wywoływania u niego takowych reakcji pod kątem osiągnięcia określonych celów. Subiektywne doświadczenia tego typu zostają zwerbalizowane, a więc z konieczności poddane autointerpretacji, czego liczne przykłady można odnaleźć zarówno w literaturze fikcyjnej czy wspomnieniowej, jak i w samych filmach, by wymienić nieśmiertelne Cinema Paradiso Giuseppe Tornatore (1988) czy rodzimą Historię kina w Popielawach Jana Jakuba Kolskiego (1998).

Koschany idzie jeszcze dalej tropem wyznaczonym przez Sontag i kieruje uwagę na sensualny, zmysłowy charakter doświadczenia filmowego; sięga przy tym do literaturoznawczego zasobu pojęciowego i lektury tekstu jako przyjemności erotycznej, znów z inspiracji Barthes'a, potem także Richarda Rorty’ego i Richarda Shustermana. Przyznaje też, że zauważalna dziś wyraźnie, także na gruncie polskiej myśli filmowej, tendencja do rozpoznania zmysłowego, „erotycznego”, wręcz cielesnego czy haptycznego aspektu odbioru dzieła pozostaje nieco spóźniona w stosunku do literaturoznawstwa (gdzie ten nurt jest już dziś mniej efektywny). Swoista moda na ten trend badawczy ma być może związek z wyłanianiem się nowego typu kinofilii odwołującego się do niegdysiejszej magii kina.

Jako znamienne, a zarazem na swój sposób wyjątkowe przykłady myślenia o cielesnych reperkusjach odbioru Koschany przywołuje pracę Vivian Sobchack 
Carnal Thoughts: Embodiment and Moving Image Culture (2004), a zwłaszcza rozdział What My Fingers Knew: The Cinesthetic Subject oraz pisaną z feministycznych pozycji książkę Laury U. Marks Skin of the Film: Intercultural Cinema, Embodiement, and the Senses (2000), która śladem Deleuze'a i Guattariego swobodnie konstruuje nośne metafory intelektualne (także te odnoszące się do zmysłowych reakcji ciała w kinie), ale równocześnie przywiązuje wielką wagę do słowa, voice-over i dialogu jako istotnego nośnika znaczeń. Wydaje się przy tym, że nie bez powodu ów typ haptycznie ukierunkowanej refleksji rozwija się na gruncie anglojęzycznym, bowiem słowo touching zawiera dwuznaczność, która odwołuje się zarówno do dotyku, jak i do wzruszenia, poruszenia emocjonalnego, podobnie jak dwuznaczne pozostają senses jako zmysły i jako odczucia. Pojawia się też wątpliwość, czy mamy tu do czynienia z czymś innym niż interpretacja, czy po prostu z inną interpretacją, skoro Sobchack wprost pisze o bu dow aniu sens ó w przez współpracę myśli i zmysłów na konkretnych przykładach.

Koschany jednak optuje raczej za pierwszym rozwiązaniem. Na poparcie tezy sięga do kilku opisów ekstremalnego doświadczenia odbiorczego związanego z filmem Mad Max: Na drodze gniewu (Mad Max: Fury Road, reż. George Miller, 2015), ale pytanie, czy taka taktyka jest ,zamiast”, czy „obok” pozostaje otwarte, niezależnie od faktu, że tu konkretnie mamy do czynienia raczej z przypadkiem wyjątkowym niż powtarzalnym.

Wreszcie alternatywne dla szeroko rozumianej interpretacji są - jak pisze autor - różne formy analizy filmowej, procedury niemal równie starej jak samo kino i budowanej na bazie wielu teorii, z reguły jednak zasadzającej się na unieruchomieniu obrazów (zwykle kadrów) filmowych i ich opisie. W krańcowych koncepcjach analitycznych następuje rezygnacja z komentarza słownego, a potencjał interpretacyjny kryje się w samym doborze i zestawieniu ilustracji. Do bardziej udanych realizacji tej metody Koschany zalicza książkę Kuby Mikurdy i Jakuba Woynarowskiego Wunderkamera. Kino Terry'ego Gilliama, będącą spójną intelektualnie graficzną prezentacją twórczości tego artysty. Autor podaje też inne udane przykłady takich rozwiązań. Kończy swoje rozważania podrozdziałem na temat wideoeseju jako autorskiej wypowiedzi na temat pojedynczych filmów lub twórców, nurtów czy kinematografii narodowych, gdzie werbalna eksplikacja zostaje zastąpiona, a częściej uzupełniona materiałem ilustracyjnym. Wymienia tu prace Kagonady czy Kevina B. Lee, Histoire(s) du cinéma Godarda i Z-boczona historię kina Sophie Fiennes. Wszystko wskazuje, że te właśnie sposoby zastępowania tradycyjnej interpretacji filmu są według niego najbardziej godne uwagi ze względu na możliwości, jakie się w nich kryją. Pewne obietnice niesie też antropologia filmu. Te ostatnie rozwiązania mają charakter w dużej mierze postulatywny, a ich rezultat zależy od talentu, wrażliwości, erudycji i pomysłowości komentującego - podobnie zresztą jak w przypadku jakiejkolwiek innej interpretacji.

Propozycja badawcza Koschanego nie jest kategoryczna i wykluczająca. Opowiada się on za użytecznością budowania nowych koncepcji na bazie dawnych, a także za interdyscyplinarnym ujmowaniem zjawisk, choć w perspektywie diachronicznej. Nie bez powodu stwierdza jednak: pojęcie interpretacji jako intelektualnej pracy nad dziełem, popartej czy poprzedzonej zdobyciem specjalistycznego warsztatu, wydaje się niezachwiane, chwieje się natomiast jej rola w naszym obcowaniu ze sztuka (s. 152). Czyżby więc romantyczny aksjomat Czucie $i$ wiara sil- 
niej mówi do mnie / Niż mędrca szkiełko i oko zyskał nową jakość za sprawą Internetu oraz mediów społecznościowych, unieważniając nadmierny rozrost intelektu, który tak niepokoił Susan Sontag, a uwalniając żywiołowe, skłębione emocje? Czy gałąź, na której siedzimy, sama powoli usycha, bo świeżość spojrzenia znaczy więcej niż autorytet uczonego? Albo też może wypada pogodzić się z tym, że uprawiamy nomen omen sztukę dla sztuki? Czas pokaże.

Warto uważnie prześledzić tok rozumowania Rafała Koschanego, choć z uwagi na gęstą strukturę wywodu nie jest to łatwe, zwłaszcza że bardzo brak indeksu nazwisk i pojęć, do których autor nawiązuje wielokrotnie w różnych rozdziałach, który pozwalałby czytelnikowi na swobodniejszą nawigację.

TERESA RUTKOWSKA

Rafał Koschany, Zamiast interpretacji. Między doświadczeniem kinematograficznym a rozumieniem filmu, Wydawnictwo Naukowe Wydziału Nauk Społecznych UAM, Poznań 2017.

${ }^{1}$ U. Eco, The Limits of Interpretation, Indiana University Press, Bloomington - Indianapolis 1994, s. 23.

${ }^{2}$ S. Sontag, Przeciw interpretacji, tłum. D. Żukowski, w: Przeciw interpretacji i inne sesje, Karakter, Kraków 2012.

${ }^{3}$ Por. H. U. Gumbrecht, Produkcja obecności. Czego znaczenie nie może przekazać, thum.
K. Hoffmann, W. Szwebs, Wydawnictwo Naukowe Uniwersytetu im. Adama Mickiewicza, Poznań 2016.

${ }^{4}$ U. Eco, dz. cyt., s. 7. 